\author{
(c) (1) (8) \\ Jurnal Terapan Manajemen dan Bisnis is licensed under \\ A Creative Commons Attribution-Non Commercial 4.0 International License.
}

\title{
THE EFFECT OF ENTREPRENEURSHIP COMPETENCY AND ADAPTABILITY OF BUSINESS ENVIRONMENT TO FINANCIAL PERFORMANCE OF SMALL AN MEDIUM BUSINESS UNITS IN BIMA CITY
}

\author{
Nurul Huda1), Aris Munandar'2), Syamsinirwani ${ }^{3)}$ \\ 1) Sekolah Tinggi Ilmu Ekonomi (STIE) Bima, Bima, Indonesia \\ E-mail: nurulhuda.stiebima@gmail.com \\ 2) Sekolah Tinggi Ilmu Ekonomi (STIE) Bima, Bima, Indonesia \\ E-mail: nurulhuda.stiebima@gmail.com \\ 3) Sekolah Tinggi Ilmu Ekonomi (STIE) Bima, Bima, Indonesia \\ E-mail: nurulhuda.stiebima@gmail.com
}

\begin{abstract}
The number of SMEs and the absorption of large manpower does not contribute greatly to the value of production and investment in the agro-industry sector and non-agro industry sector is a reflection of most SMEs in Bima city. This problem occurs because there are so many considerations of it, one of them is lack of competence of SMEs business sector, the limitations in the ability to adapt with the environment changes including market of innovation, access to information and financing, the difficulty in the procurement of capital and cheap, the limitations in innovation, technology changing that will affect all business performance of SMEs. The higher social competence (interaction, social relations, and social adaptation) owned by entrepreneurs, the greater financial success that entrepreneurs will achieve and improve business performance. The research method used is explanatory research by using a survey sampling approach. Conventionally, explanatory research is used to explain the relationship between variables through hypothesis testing. Then, the questionnaires will be distributed 156 SMEs in Bima city where the questionnaire have tested the validity and reliability then processed by using SPSS so that the accuracy of analytical tools can be reliable. The long-term goal to be achieved is increasing the competitive advantage and performance of SMEs throughout Bima city. The specific targets of this research are the enhancement of competitive advantage and performance of SMEs in Bima city with the entrepreneurial competence that is able to build business network and assimilate to external environment changes that encourage the efficient use of resources, improving the ability to build business networks, multiple sources of economic growth, create employment, networking in collaboration with business partners and enhancement of competitiveness, a better service for clients and customers are need to be improved where they are not dependent on imported products that undermine the society economic tenacity, the ability to express themselves in constructing social relationship. The results of the t-test statistic for the obtained variable are $\mathrm{t}$-count of 5.964 with a t-table value of $1.645(5.964>1.661)$ with a significance value of 0.000 less than $0.05(0.000<0.05)$, the hypothesis that "Entrepreneurship competency influences SME financial performance in Bima City". The results of the t-test
\end{abstract}


statistic for the obtained variable are t-count of 0.373 with a t-table value of $1.645(0.373<$ $1.645)$ with a significance value of 0.710 greater than $0.05(0.710>0.05)$, hence the hypothesis that "Environmental Adaptability Business influences the financial performance of SMEs in Bima city.

Keywords: Entrepreneurship Competence; Environmental Adaptability; SME Financial Performance

\section{Introduction}

The important and strategic role of Small and Medium Enterprises for the economic growth of the country, both developing and developed countries is no doubt. Small and medium enterprises are not only able to absorb labor compared to large businesses but also contribute to the greatest growth of gross domestic product (GDP) compared to large businesses (Tambunan, 2009). The advantages of SMEs are the main flexibility in changing their business according to market demands. Although such existence of SMEs also experienced many obstacles that hampered the growth of SMEs caused by external and internal parties.

The number of SMEs and the employment of many who do not provide a large contribution to the value of production and investment value in the agro-industry sector and the non-agro-industrial sector is a mirror of most SMEs in the city of Bima. This problem occurs because of many considerations, one of them is the weak competency of entrepreneurs in the SME sector, limitations in the ability to adapt to changes in the environment including the market in innovation, access to information and financing, difficulties in procuring and cheap capital, limitations in innovation, technological changes that will all affect on SME business performance. The higher social competence (social interaction, social relations, social adaptation) owned by the entrepreneur, the greater the financial success that the entrepreneur will achieve and improve business performance (Baron and Markman, 2003).

Some research literature also found theoretical contradictions, namely the existence of a research gap, which states that entrepreneurial competence has a positive influence on company performance (Baron and Markman, 2003). Some other research results state that competence does not have an influence on company performance, where entrepreneurial competence is explained in This form of social interaction will sometimes limit access to information if only for certain groups so that it does not have an impact on performance (Murphy, 2002). In addition, there are opinions about the components of innovation that have a negative and positive effect on the performance of SMEs, according to Malecki (2000), social capital owned by entrepreneurs through information exchange will encourage the emergence of innovation that will improve performance. With regard to environmental adaptability according to Baker and Sinkula (2009) is the implementation of market-oriented strategies, consumer taste orientation, technology change allows companies to adapt successfully to environmental changes. Market orientation is significantly an important factor that allows companies to understand markets and develop product and service strategies to meet customer needs and market needs, which means that the greater the market orientation of a company, the greater the overall performance.

By looking at the background of the above problems it is necessary to find a solution to all the obstacles that are still experienced by small and medium business units, one alternative solution is the need to conduct research entitled the influence of entrepreneurial competence and business environment adaptability to SME performance. Described with the ability to build social business relationships and adapt to the business environment such as 
adapting to consumer tastes, market changes, competition, policy changes, technological changes so innovative in developing new products, responding to product changes and market tastes, creative in providing services and new technology.

The long-term goal to be achieved is to increase the competitive advantage and performance of SMEs throughout the City of Bima. The specific target of this research is to increase competitive advantage and the performance of SMEs in Bima City with the existence of entrepreneurial competencies that are able to build business networks and adapt to changes in the external environment encourage efficient use of resources, increase the ability to build business networks, increase the source of economic growth, creation employment, increased networking (networking) in collaboration with business partners and increased competitiveness, better services to clients and customers need to be improved which does not depend on imported products that weaken the overall economic resilience of the people, the ability to express themselves in building social relations.

Output targets to be achieved Give contributions to owners, founders, supervisors, people who lead SMEs to be able to use the dimensions and factors as well as entrepreneurial competencies as well as other forms of innovative adaptability strategies to develop appropriate approaches in achieving SME performance improvement. From the background above, the following problems can be formulated:

1. Does Entrepreneurship Competence affect the financial performance of SMEs in Bima City?

2. Does Environmental Adaptability affect the Financial Performance of SMEs in Bima City?

3. Which of the variables of Entrepreneurship Competency and Business Environment Adaptability have a dominant influence on the financial performance of SMEs in Bima City?

\section{Research Methods}

The type of data used in this study is Primary data, namely data obtained from respondents' answers to questions posed by researchers. The population of this study is small and medium enterprises in the city of Bima. Small and medium enterprises that are sampled are 156 SMEs out of 156 SMEs who are population. Reason Sampling technique using purposive sampling Data collection used was purposive sampling. Purposive sampling is a method of collecting data by taking elements or members of the population as a whole with the aim of processing the entire data that is returned (Sugiyono, 2016).

The variables in this study are Entrepreneurial Social Competency as independent variables (X1), Adaptability of Business Environment (X2) and Financial Performance of SMEs as the dependent variable $(Y)$ with several indicators as a benchmark to see the effect between variables $\mathrm{X} 1, \mathrm{X} 2$ and $\mathrm{Y}$ variables. variable using Likert's scale.

Data collection techniques used in this study, namely (1) Questionnaire, (2) Observation, (3) Literature study. Testing the data using validity test by stating that if the validity of each statement is greater than 0.30 or $>0.30$ then the question item is considered valid and reliability testing is determined by the Cronbach's Alpha coefficient by requiring a reliable instrument if it has a Cronbach's Alpha coefficient above 0.60 or $>0.60$. The data analysis technique used is multiple linear regression analysis using the equation, $\mathrm{Y}=\alpha+\mathrm{bX} 1$ $+\mathrm{b} 2 \mathrm{X} 2$.

To test the hypothesis in this study used a multiple linear regression analysis models. In this analysis, the financial performance measures of SMEs are regressed with entrepreneurial social competence and the adaptability of the business environment. The 
testing procedure for each hypothesis starts with a partial test (regression coefficient) or called the t-test, which tests the significance of constants and independent variables contained in the equation individually whether it affects the dependent variable (Ghozali, 2005).

The hypothesis in t-test is $\mathrm{H} 0$, meaning that there is no significant effect on $\mathrm{Y}$, while $\mathrm{H} 1$ means that variable $\mathrm{X}$ has a significant effect on $\mathrm{Y}$. $\mathrm{H} 0$ is rejected and $\mathrm{H} 1$ is accepted if the value of $t$ counts more than $t$ table ( $t$-hit $>t-t a b)$. In the regression analysis and test, this is done using SPSS 20 for windows. Against the variables, correlation analysis is performed to determine the shape and strength of the relationship of the independent variables to the dependent variable.

\section{Result And Discussion}

Validity test

Table 1 Validity Test Results

\begin{tabular}{lllll}
\hline $\begin{array}{c}\text { r. Calculate } \\
\text { Variable X1 }\end{array}$ & $\begin{array}{c}\text { r. Calculate } \\
\text { Variable X2 }\end{array}$ & $\begin{array}{c}\text { r. Calculate } \\
\text { Variable Y }\end{array}$ & $\begin{array}{c}\text { r. } \\
\text { Table }\end{array}$ & Description \\
\hline$(X 1.1) 0,463$ & $(X 2.1) 0,717$ & $($ Y.1) 0,771 & 0,300 & Valid \\
$(X 1.2) 0,645$ & $(X 2.2) 0,697$ & $(Y .2) 0,827$ & 0,300 & Valid \\
$(X 1.3) 0,687$ & $(X 2.3) 0,619$ & $(Y .3) 0,829$ & 0,300 & Valid \\
$(X 1.4) 0,677$ & $(X 2.4) 0,417$ & & 0,300 & Valid \\
$(X 1.5) 0,476$ & $(X 2.5) 0,321$ & & 0,300 & Valid \\
$(X 1.6) 0,390$ & & & 0,300 & Valid \\
$(X 1.7) 0,585$ & & & 0,300 & Valid \\
$(X 1.8) 0,664$ & & & 0,300 & Valid \\
\hline
\end{tabular}

Source: Data processed in 2018

Based on Table 1, the results of testing the validity of Entrepreneurship Competency and Business Environment Adaptability variables on Financial Performance can be said to be valid on Corrected items - total correlation $>0.300$. The results of testing this validity indicate that the questionnaire statement in this study is valid.

\section{Reliability Test}

Table 2 Reliability Test Results

\begin{tabular}{lcc}
\hline \multicolumn{1}{c}{ Variable } & CronbachAlpha & Description \\
\hline Entrepreneurship Competence (X1) & .710 & Reliable \\
Business Environment Adaptability (X2) & .710 & Reliable \\
Financial Performance (Y) & .736 & Reliable \\
\hline Source: Data processed in 2018 & &
\end{tabular}

Based on Table 2 The results of testing the study using this measurement can be said to be reliable on Cronbach's alpha $>0.600$. The results of this reliability test indicate that the questionnaire statement in this study is reliable.

\section{Descriptive Statistics Analysis}

The descriptive statistical analysis is used to find out the description or description which includes the average value, as well as the standard deviation value of the variables in 
the study. For this study, there were 156 samples of SME participants. The classic rage value of SME Entrepreneurship Competence is 33.9038 with a standard deviation of 3.32494. This result shows that the average entrepreneurial competency of a company is greater than the standard deviation. This show as good results. The average value of SME Business Adaptability of 21.0385 is greater than the standard deviation of 1.71853 . This also shows good results. as well as the average value of SME Financial Performance of 12.5128 greater than the standard deviation of 1.70951.

\section{Classic assumption test}

The classic assumption test is carried out to obtain an unbiased and efficient estimator value from the regression equation with the ordinary least square method. Therefore, in the implementation of data analysis must meet the classical assumptions. Testing the regression model includes the assumption of normality, multicollinearity, heterogenicity, and autocorrelation. The description of the calculation testing the assumption of the regression model can be explained.

For testing the normality of the data in this study using the graph method and the Kolmogorov-Smirnov test. This study uses two independent variables, then testing the normality of the data is divided into data from the plot of regression sequences that can For Testing Normality be concluded that the regression side has spread normally because the sisal pattern approaches the diagonal line pattern. Besides that, the Kolmogorov-Smirnov test was obtained, the significance value $\alpha=0.200>0.05$ (based on the regression model) means that the normality test is fulfilled.

For the Multicollinearity Test in this study in detecting the presence or absence of multicollinearity can be seen from the Variance Inflation Factor (VIF). If the VIF value is $>10$, it indicates multicollinearity. If the opposite is VIF $<10$ then multicollinearity does not occur. For the Multicollinearity Test in this study, it concludes collinearity of the transformations shows a VIF value of no more than 10, there is no multicollinearity.

For the Heteroscedasticity Test in this study carried out by looking at the plot graph. Indications of the occurrence of heteroscedasticity appear in certain patterns formed in the plot. If there is no particular pattern and the spread points above and below the $\mathrm{Y}$-axis $=0$, heteroscedasticity is not indicated. In this study, the plot above can be seen that the plot points do not form a specific pattern to spread are Autocorrelation. Therefore it can be concluded that there is no heteroscedasticity.

For the Autocorrelation Test in this study conducted by examining the presence or absence of autocorrelation in the regression of the dependent variable is done by checking the statistics of Durbin-Watson (DW). Autocorrelation Test Results Based on SPSS Version 17.0 output, the Durbin-Watson test results show that $1.7642<2.111<2.2358$. Can be seen based on criterion number 2 If $\mathrm{dU}<\mathrm{D}-\mathrm{W}<4-\mathrm{dU}$, the conclusion is that there is no autocorrelation. $\mathrm{W}$ test value is in the area where there is no autocorrelation it can be concluded that the resulting regression equation does, not have a number of autocorrelations.

\section{Hypothesis Test Results}

Next, to find out whether the hypothesis proposed in this study is accepted stably ejected, it will be tested by using the t-test. The results of hypothesis testing are explained as follows: 
Table 3 Coefficients ${ }^{a}$

\begin{tabular}{|c|c|c|c|c|c|c|}
\hline \multirow[t]{2}{*}{ Model } & & \multicolumn{2}{|c|}{$\begin{array}{l}\text { Unstandardized } \\
\text { Coefficients }\end{array}$} & \multirow{2}{*}{$\begin{array}{c}\begin{array}{c}\text { Standardized } \\
\text { Coefficients }\end{array} \\
\text { Beta } \\
\end{array}$} & \multirow[t]{2}{*}{$\mathbf{t}$} & \multirow[t]{2}{*}{ Sig. } \\
\hline & & B & Std. Error & & & \\
\hline \multirow{3}{*}{1} & (Constant) & 2.007 & 1.176 & & 1.706 & .090 \\
\hline & $\mathrm{X} 1$ & .330 & .055 & .643 & 5.964 & .000 \\
\hline & X2 & -.033 & .088 & -.040 & -.373 & .710 \\
\hline
\end{tabular}

a. Dependent Variable: $Y$

Source: Data processed

\section{Testing of the First Hypothesis}

The results of the $t$-test statistic for the obtained variable are $t$-count of 5.964 with a $t$ table value of $1,645(5.964>1.661)$ with a significance value of 0.000 less than $0.05(0.000<$ 0.05), the hypothesis that "Entrepreneurship competency influences SME financial performance in Bima City "Received Hypothesis 1". This gives the meaning that the development of entrepreneurial social competence consists of the ability to build business relationships with suppliers such as exchanging information, subscribing to raw materials at low prices and good quality, building business relationships based on social relationships with fellow entrepreneurs. Build social closeness with employees such as giving incentives, providing skills, education, while building closeness with customers such as giving discounts and quality according to selling prices, as well as gifts for potential customers, providing free consultations according to their expertise, friendly service, providing credit facilities for large customers, free delivery service while still in town, able to improve business networks that lead to competitive advantage and improving the performance of SMEs. Building social closeness with the government such as business licensing and as a speaker on governmentassisted programs. Competence in the form of social-cultural wisdom owned by the people of Bima City can improve the competitiveness and excellence of SME businesses in the City of Bima. Companies that manage Maximum Entrepreneurial Competence can create valueadded and competitive advantages that will lead to improving SME Performance.

\section{Testing of the Second Hypothesis}

The results of the t-test statistic for the obtained variable are $t$-count of 0.373 with a $t$ table value of $1.645(0.373<1.645)$ with a significance value of 0.710 greater than $0.05(0.710>$ 0.05), hence the hypothesis that "Environmental Adaptability Business influences the financial performance of SMEs in Bima city "Rejected Hypothesis 2". This indicates that SMEs in the city of Bima have not been able to adapt to changes in the environment, creating strategies that are oriented to competitive advantage and improve the performance of SMEs. The test here can be interpreted that most SMEs in Bima City does not yet have the ability to manage, adapt to the environment well, adapt to government policies such as the nation's children's love movement can increase SME profit, high innovation creativity such as antique and characterized product design distinctive, varied, the use of new technologies such as advertising through Facebook, Twitter, the Web Blog, responding to market tastes such as serving specialties made from hardwood such as teak, Bengkirai wood, Merbau wood, will create a strategy that is oriented to competitive advantage and enhances SME Performance

\section{Testing of the Second Hypothesis}

Based on the results of the research that has been done, it can be seen the most dominant variable in the study To determine the most dominant independent variable on 
SME financial performance, namely by looking at the significance of the smallest value. The variable that has the dominant influence on SME financial performance is Entrepreneurship Competence with the smallest significance value (0.000).

\section{Conclusion}

The conclusions from this study are as follows

a. The development of entrepreneurial social competency which consists of the ability to build business relationships based on social kinship, build social closeness with employees and customers are able to improve business networks that lead to competitive advantage and increase the performance of SMEs.

b. Competence in the form of social-cultural wisdom possessed by Semarang society can improve the competitiveness and superiority of SME businesses in Bima City.

c. Most SMEs in Bima city has not been able to manage, adapt to the environment well, high innovation creativity such as antique and distinctive product design, use of new technologies, responding to market tastes will performance's that are oriented to competitive advantage and improve SME Performance.

\section{Suggestion}

Environmental adaptability that develops in SMEs has not been maximized such as adjusting consumer tastes, adjusting government regulations and adjusting new technologies, so it is advisable to further implement Entrepreneurship Competencies, Innovation Creativity, increase adaptation to changing consumer tastes so that they have their own characteristics and increase competitiveness which is a trend on the market. The ability to manage and adapt the environment well will create a strategy that is oriented to competitive advantage.

\section{References}

Baker, W. E., and Sinkula, J. M. (2009). The Synergistic Effect of Market Orientation and Learning Orientation on Organizational Performance. Journal of the Academy of MarketingScience, 27, 411-427.

Baron, R. A., and Markaman. (2003). Beyond social capital: the role of entrepreneurs' social competences in their financial success. Journal of Business Venturing 18, 41-46.

Ghozali, Imam. (2005). Aplikasi Analisis Multivariate dengan Program SPSS. Semarang: Universitas Diponegoro.

Malecki, E.G. (2000). Entrepreneurs, networks and economic development: A review of recent research.

Murphy, J.T. (2002). 'Networks, Trust, and Innovation in Tanzania's Manufacturing Sectors. World Development, 30(44), 591-619.

Sugiyono. (2016). Metode Penelitian Kuantitatif Kualitatif dan RED. Bandung: Alfabeta.

Tambunan, Tulus T. H. (2009). Perekonomian Indonesia. Bogor: Ghalia Indonesia. 